\title{
THE IMPACT TAX KNOWLEDGE, TAX AWARENESS, TAX MORALE TOWARD TAX COMPLIANCE BOARDING HOUSE TAX
}

\author{
Hantono ${ }^{* 1}$ 浭 \\ ${ }^{* 1}$ Faculty of Economy, Accounting, University of Pelita Harapan (Medan City) Lippo Plaza Medan, \\ Lantai 5 - 7, Jl. Imam Bonjol No.6, Indonesia
}

DOI: https://doi.org/10.29121/granthaalayah.v9.i1.2021.2966

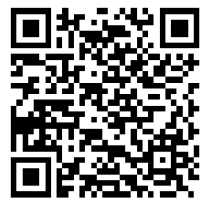

Article Type: Research Article

Article Citation: Hantono (2021). THE IMPACT TAX KNOWLEDGE, TAX AWARENESS, TAX MORALE TOWARD TAX COMPLIANCE BOARDING HOUSE TAX. International Journal of Research GRANTHAALAYAH, 9(1), 49-65. https://doi.org/10.29121/granthaa layah.v9.i1.2021.2966

Received Date: 20 December 2020

Accepted Date: 25 January 2021

Keywords:

Tax Knowledge

Tax Awareness

Tax Morale

Tax Compliance

\section{ABSTRACT}

This study aims to determine the effect of 1) tax knowledge, 2) tax awareness, 3) tax morale, 4) tax compliance. The sampling in this research was conducted by using an incidental sampling method. Methods of data collection through questionnaires that have been distributed to 100 respondents who have met the criteria. Multiple linear regression analysis shows that tax knowledge, tax awareness, and tax morale are significant toward tax compliance. The simultaneous have a significant effect on tax compliance. It can be concluded that tax knowledge mitigation, tax awareness, and tax morale towards tax compliance. The results of t-test showed that tax knowledge isn't approved and indicates it has a significant impact on affecting tax compliance, tax awareness is approved, and indicates has less impact on affecting tax compliance, tax morale isn't approved. It indicates has a great impact on affecting tax compliance. The results of $\mathrm{F}$ test showed that both of the independent variables are simultaneously affecting tax compliance. R Square's result is 0.710 , which shows that $71 \%$ of tax compliance mitigation can be explained by tax knowledge, tax awareness, and tax morale. Simultaneously, $29 \%$ of tax compliance variables can be explained by other factors or variables not examined in this research.

\section{INTRODUCTION}

Taxpayer compliance is one of the keys to guaranteeing the government's success in collecting tax revenue so that it can be used to support development financing. The income tax that is levied on the boarding business is final $\mathrm{PPh}$. According to Government Regulation of the Republic of Indonesia No. 46 of 2013, the final income tax is imposed on personal and corporate taxpayers with a turnover of under 4.8 billion rupiah in one year. As stated in the following quote:

Article 2 paragraph (1):

"For income from businesses that are received or obtained by taxpayers who have a certain gross circulation, they will be subject to final income tax.".

Based on the contents of paragraph (1), boarding house businesses or boarding businesses, including taxable objects, are subject to final income tax.

Final income tax is also referred to as income tax article 4 paragraph (2), which has different rates for each income type. The boarding business tax itself is subject to a tariff of $1 \%$ of the total income received in one month. As stated in article 3 of the Government Regulation of the Republic of Indonesia No. 46 of 2013. Based on Law No,

(C) 2021 The Author(s). This is an open access article distributed under the terms of the Creative Commons Attribution License, which permits unrestricted use, distribution, and reproduction in any medium, provided the original author and source are credited. 
The Impact Tax Knowledge, Tax Awareness, Tax Morale Toward Tax Compliance Boarding House Tax

28/2009 on Regional Taxes and Regional Retribution (PDRD) Article 1 number 21 Hotel is a service provider facility lodging/rest including other related services for a fee, which includes a motel, inns, tourism shacks, tourism guest houses, guest houses, lodging houses and the like, as well boarding house with more than 10 (ten) rooms. Article 35 Paragraph (1) PDRD Law Hotel Tax Rates are set at a maximum of 10\% (ten percent).

\section{LITERATURE REVIEW}

\subsection{TAX KNOWLEDGE}

Tax knowledge is the level of awareness or sensitivity of the taxpayers to tax legislation. Tax knowledge refers to the processes by which taxpayers become aware of tax legislation and other tax-related information

Tax knowledge is the process by which taxpayers know about taxation and apply that knowledge to pay taxes. Knowledge and understanding taxation regulations in question are understanding and understanding concerning general provisions and procedures for taxation (KUP), which cover how to deliver notification letter (SPT), payment, place payment, penalties, and the deadline for payment or reporting SPT (Resmi, 2009).

According to Rajif (2012), understanding These include (1) letter filling Notification (SPT) correctly so that Taxpayers (WP) must have an understanding which is sufficient regarding filling the SPT, (2) tax calculation following tax payable owed by W.P., so W.P. must have sufficient understanding in calculating the tax payable borne by W.P., (3) tax payment (payment) promptly according to which specified, so W.P. must have sufficient knowledge about things that are related to tax payments, (4) reporting of taxes to the tax office local by W.P. If W.P. has sufficient knowledge of all four things above mentioned, taxpayers can well do all provisions fulfillment of tax obligations.

Tax knowledge is the taxpayer's ability to know the tax regulations both about the rates based on the law paid or tax benefits that are useful for mutual needs. Someone who has an education will be aware of and obedient to their rights and rights obligations without being forced and threatened by several sanctions or penalties. Knowledgeable taxpayers will have a self-conscious attitude towards compliance pay for their obligations (Hartini, 2018).

Knowledge of taxation is a condition where taxpayers know and understand the general provisions and procedures for taxation that are the reference for implementation taxation, including applicable laws and regulations (Harefa, 2019).

Widayati and Nurlis (2010) define knowledge as an outcome of thinking that changes don't know and eliminate doubts on a case. The public should know and understand regulations taxation due to fulfilling taxation obligations; taxpayers need to know about taxes first. An understanding of taxation is expected to encourage the awareness of taxpayers to fulfill tax obligations.

\subsection{AWARENESS}

Tax awareness is a thing the condition of someone knowing, recognizing, respecting, and obeying tax provisions that apply and have sincerity and desire to fulfill obligations taxation (Muliari and Setiawan, 2011).

This awareness of paying taxes leads to obedience, obedience, and more discipline, and a critical attitude. The more developed the community and government, the higher the awareness of paying taxes, but it does not stop there. They are increasingly critical in addressing taxation issues, especially in the policy material taxation area (Jotopurnomo, 2013).

Consciousness is a state of knowing, while taxation is a matter of taxation, so tax awareness is a state know or understands about tax (Yusnidar, 2015).

Awareness required tax is where the taxpayer understands and finds out about taxes without coercion from any party. A positive assessment from the community is mandatory tax on the implementation of a country's functions can make society obey obligations and pay taxes (Ummah, 2015).

Tax awareness is the willingness to fulfill the obligation and contribute to that country's development. Awareness of the taxpayer has logical consequences for the mandatory tax, that is, the taxpayer's willingness to provide a contribution of funds for the implementation of functions taxation by paying the right taxes time and exact amount (Subarkah, 2017). 


\subsection{TAX MORALE}

Alm and Torgler (2006) defined tax morale as 'the intrinsic motivation to pay taxes.' Tax moral measures an individual's willingness to pay taxes, that is, 'the moral obligation to pay taxes' or 'the belief that paying taxes contributes to society.' Tax morale is defined as instructive motivation to pay taxes (Torgler, 2007). A moral obligation is an individual norm that belongs to

someone, but it may not be owned by someone else. In doing an action, individuals usually pay attention to values believed in themselves (Dewi, 2016).

\subsection{TAX COMPLIANCE}

James and Alley (2012) tax compliance is a significant problem for many tax authorities. It is not easy to persuade taxpayers to comply with tax requirements even as the tax laws are not always precise in some respects. Cuccia (2013) conducted his studies in Brazil, defined tax compliance as filing all required tax returns at the proper time and accurately report tax liability according to the tax law applicable when the return is filed.

Tax compliance is interpreted freely as adherence in conducting all tax regulations (Damajanti, 2017).

Tax compliance can be defined as the degree to which a taxpayer complies or fails to comply with their country's tax rules (Marziana et al., 2010).

Tax compliance is of paramount importance for the government to provide public goods and reallocate wealth (Jayawardane, 2016).

Tax compliance is fulfilling all the tax obligations, as stated by the law, willingly and fully (Marti, 2010).

\section{The Impact of Tax Knowledge Towards Individual Taxpayer's Compliance}

More significant knowledge taxpayers, then the more prominent, too compliance pay taxes (Winasari, 2020).

This proves that in meeting on tax, compliance does not need to have high knowledge about taxes. Knowledge of society's tax laws through awareness will positively affect the taxpayer's consciousness to pay taxes (Lestari, 2017). Tax knowledge is knowledge about the concept of general provisions in the field of taxation, the kinds of taxes which applied in Indonesia starting from the subject of tax, object tax, tax rates, calculation of tax payable, recording of tax payable, until how to fill in tax reporting (Yusuf and Ismail, 2017). Tax knowledge owned by taxpayers could increase taxpayer's compliance. It is suitable for Indonesia's taxation system, which adheres to a self-assessment system that requires taxpayers to know tax regulations. By having adequate tax knowledge, taxpayers could carry out tax obligations that should be done. Lack of tax knowledge is a cause of low tax compliance. Besides that, taxpayers' knowledge about tax could be obtained from tax officers, television, internet, newspapers, taxation books, tax socializations, and some training. Increased taxpayers' insight can increase the importance of taxes for them, society, and the country (Setiawan, 2019). It's also supported by research doing by Waluyo (2012). Yusuf and Ismail (2017) state that tax knowledge positively affects a taxpayer's compliance. Based on the description above, the hypothesis is formulated as follows:

H1: Tax Knowledge has a Positive Impact on Individual Taxpayer's Compliance.

\section{The Impact of Tax Awareness on Taxpayers Compliance}

The better awareness of taxpayers, the better compliance of taxpayers (Ariesta, 2017). The higher the awareness of the taxpayer, the higher the taxpayer compliance (Lydiana, 2018). Increased taxation knowledge through good tax education, formal or informal, will impact Taxpayers for Pay Taxes (Hardiningsih, 2011). This proves that the higher the taxpayer's awareness, the higher tax compliance (Lestari, 2017). The research results presented by (Al - Maghrebi et al., 2016), where their research results also revealed that the awareness of taxes affects taxpayer compliance. In their research, the obedient individual or who will obey is an individual who has awareness about taxation. Having the awareness that paying taxes is mandatory and can finance the state. The higher the taxpayers' level of tax knowledge, the higher the tax compliance rate taxpayer (Puspita, 2016). Taxpayers who are aware of their rights and obligations as citizens will carry out their obligations without coercion for the construction of facilities and infrastructure that will be carried out by the government through tax collection on income received by the taxpayer for sales revenue. In the guidebook, the rights and obligations of the taxpayer (2011: 
3). The greater it is, and the higher the level of taxation knowledge and understanding, the higher the taxpayer compliance level (Asfa and Meiranto, 2017). Based on the description above, the hypothesis is formulated as follows:

H2: Tax Awareness has a Positive Impact on Individual Taxpayer's Compliance.

\section{The Impact Tax Morale Towards Individual Taxpayer's Compliance}

Tax morale affects tax compliance behavior, i.e., a higher (lower) tax morale reduces (increases) the level of tax evasion (Frey and Torgler, 2007; Halla, 2010). Moral obligation is very closely related to awareness of taxpayers, morals owned by taxpayers such as ethics, principles of life, feelings of guilt if not paying taxes, if the morale of the taxpayer is good, the taxpayer will be aware of fulfilling his tax obligations (Semaraputri,2019). A reasonable taxpayer's moral obligation will create a will to calculate voluntarily, pay, and report taxes followed by compliance with applicable tax rules that will directly affect compliance (Layata, 2014). Moral obligations are individual morals owned by someone but possibly not owned by someone else (Agustini, 2008). The taxpayer has ethics, principles of life, feelings of guilt, carrying out tax obligations voluntarily and correctly, which is later linked to fulfillment obligation. Taxpayers feel guilty if they don't fulfill obligations to taxation (Artha, 2016). The moral is that the taxpayer's goodwill creates a willingness to pay and report its taxes by complying with applicable tax rules and possession awareness that through taxes can help government development and directly affect compliance in meeting obligations tax (Dewi, 2016). Morality is the behavior that governs taxpayer relationships as a citizen with the government (Yadnyana,2010). Compliance with tax reporting will increase if the Taxpayer has a more vital moral responsibility $(\mathrm{Ho}, 2009)$. If the taxpayer has a sizeable moral responsibility, then the fulfillment of tax obligations is high. There is a moral responsibility; it will encourage someone to be obedient in their tax reporting (Rosito, 2010). Based on the description above, the hypothesis is formulated as follows:

H3: Tax Morale has a Positive Impact on Tax Compliance.

\section{RESEARCH METHOD}

\subsection{VARIABLE MEASUREMENT}

Measurement is the determination of numbers or other symbols for objects' characteristics according to a set of predefined rules. A scale is a tool or mechanism by which individuals differentiate individuals from other individuals toward research variables. Measurement of all variables in this research is using Likert Summated Ratings (LSR)method. Likert scale is used to measure attitudes, opinions, and perceptions of a person or group of people about social phenomena (Sugiyono 2017). The details of the scale are as follows:

Scale $1=$ Strongly disagree

Scale $2=$ Disagree

Scale $3=$ Neutral

Scale $4=$ Agree

Scale 5 = Strongly agree

\subsection{DATA ANALYSIS METHOD}

In the first stage, the questionnaire must be tested by the validity and reliability tests. The validity indicates whether the instrument has measured something correctly. The reliability indicates the stability and consistency of whether the instrument measures the concept and helps determine the accuracy or goodness. The data analysis method used in this research is the multiple regression method. Multiple regression is an analytical tool used to test the causality relationship of one dependent variable and several independent variables. The steps taken in multiple regression analysis are a descriptive statistic, classical assumption test, simultaneous hypothesis testing, coefficient of determination, and partial hypothesis testing (Chandrarin 2017).

Validity test

A validity test is used to measure the validity of a questionnaire. A questionnaire is valid if the questionnaire's question can explain something that will be measured on that questionnaire (Ghozali, 2016). This test is done by 
comparing the value of rcount with rtable for degree of freedom (df) $=n-2$; in this case, $n$ is the number of samples. The criteria as follows:

1) rcount $>$ rtable, means that the question in the questionnaire is valid.

2) rcount $<$ rtable, it means that the question in the questionnaire is not valid.

\section{Reliability Test}

A reliability test is a tool to measure a questionnaire that is an indicator of a variable or constructs. A questionnaire is reliable if one's answers to questions or statements are consistent or stable over time. Reliability testing is done by calculating the Cronbach Alpha Coefficient amount for each questionnaire instrument to be tested. According to Widiyanto (2010: 43), a variable is reliable if

1) Cronbach Alpha Coeficcient $>$ rtable, it means that the question in the questionnaire is valid.

2) Cronbach Alpha Coeficcient $<$ rtable means that the questionnaire's question is not valid.

\subsection{DESCRIPTIVE STATISTIC TEST}

According to Chandrarin (2017), a descriptive statistics test is conducted to test and explain the observed sample's characteristics. Descriptive statistics test results are usually in the form of a table containing the name of the observed variables, the mean, standard deviation, maximum and minimum, followed by explanations in the form of narratives that explain the interpretation of the table's contents.

\section{Classical Assumption Test}

A classical assumption test is conducted to examine the validity of the regression model applied to fulfilling requirements. There are four steps in conducting the classical assumption test: normality test, multicollinearity test; autocorrelation test; and heteroscedasticity test. In this research, the data used in cross-section data. Cross-sectional data is a type of data taken at one shoot time within a particular measurement attribute's appropriate constraint. Cross-sectional data is determined based on variations of data taken at a given time. Autocorrelation is not used in the data section (Chandrarin, 2017). Therefore, in this research, do the normality test, multicollinearity test, and heteroscedasticity test.

\section{Normality Test}

Hantono (2020) stated that the normality test is used to determine whether the data population is normally distributed or not. If the residuals are not normally distributed, the statistical test will be invalid for the small sample. There are two methods in respect of examining the data is normally distributed, which are graphical analysis and statistical analysis.

\section{Multicollinearity Test}

According to Hantono (2020), the multicollinearity test is used to see the relationship between the independent variables. The simple linear regression test does not use the multicollinearity test because it only has one independent variable. An appropriate regression model should not correlate with its independent variables. If independent variables are correlated, these variables are not orthogonal. The orthogonal variable is the independent variable that the correlation value among the independent variables equals zero.

\section{Heteroscedasticity Test}

According to Hantono (2020), the Heteroscedasticity test is a test that assesses whether there is an inequality of variance from the residuals for all observations in the linear regression model. If the variance is similar, the homoscedasticity exists. An appropriate regression model should have its residuals to be homogenous.

\section{Multiple Linear Regression}

This research used a multiple linear regression model because it involves two independent variables and one dependent variable. The regression model in this research is as follows:

$$
\mathrm{Y}=\alpha+\beta \_1 \mathrm{X} 1+\beta \_2 \mathrm{X} 2+\beta \_3 \mathrm{X} 3+\mathrm{e}
$$


The Impact Tax Knowledge, Tax Awareness, Tax Morale Toward Tax Compliance Boarding House Tax

Where:

$\mathrm{Y}=$ Tax Compliance

$\alpha=$ Constanta

$\beta 1,2=$ Coefficient regression

$\mathrm{X} 1,2,3=$ Tax Knowledge, Tax Awareness, Tax Morale

e $=$ Standard Error

\section{Partial Hypothesis Testing (T-Test)}

T-test shows the extent to which an independent variable can individually explain the dependent variable (Chandrarin 2017). The hypothesis is accepted or rejected through a t-test with the following criteria:

1) When significance level $\leq 0.05$ or tcount $>$ ttable, it means independent variable individually affects the dependent variable.

2) When significance level $\geq 0.05$ or tcount $<$ ttable, it means independent variable does not individually affect dependent variable.

\section{Simultaneous Hypothesis Testing (F-Test)}

F-test shows whether independent variables simultaneously affect the dependent variable within the regression model (Ghozali 2016). The requirements of $\mathrm{F}$ test are:

1) 1.If the level of significance $\mathrm{F}<0.05$ or Fcount $>$ Ftable, independent variables simultaneously have a significant impact on dependent variables.

2) 2.If the level of significance $F>0.05$ or Ftable $<$ Fcount, independent variables do not simultaneously significantly impact dependent variables.

\section{Coefficient of Determination (R2)}

The coefficient of determination test is an indicator that shows the proportion of independent variables' variation, which can explain the variation of the dependent variable. Low value of R2 indicates that the independent variables have a low ability to explain the dependent variable. The value that is nearly one means that the independent variables can describe all information required in predicting the dependent variable. In general, research that uses cross-sectional data can relatively have a low coefficient of determination because of each observation's large variations (Chandrarin 2017).

\section{ANALYSIS}

\subsection{CLASSIFICATION OF RESPONDENTS' CHARACTERISTICS}

The respondents' four characteristics in this research are divided by their gender, age, education status, and occupation.

Table 1: Respondents' Characteristics by gender

Gender

\begin{tabular}{|c|c|c|c|c|c|}
\hline & & Frequency & Percent & Valid Percent & Cumulative Percent \\
\hline \multirow{3}{*}{ Valid } & \multirow{3}{*}{$\begin{array}{c}\text { Male } \\
\text { Female } \\
\text { Total }\end{array}$} & 21 & 21.0 & 21.0 & 21.0 \\
\hline & & 79 & 79.0 & 79.0 & 100.0 \\
\hline & & 100 & 100.0 & 100.0 & \\
\hline
\end{tabular}

Source: Processed Data (2020)

The table above shows the gender of the respondents. The distributions between male and female respondents are 79 percent and 21 percent, respectively. This means some more female individual taxpayers answered the given questionnaires compared to that of males. 


\section{Hantono}

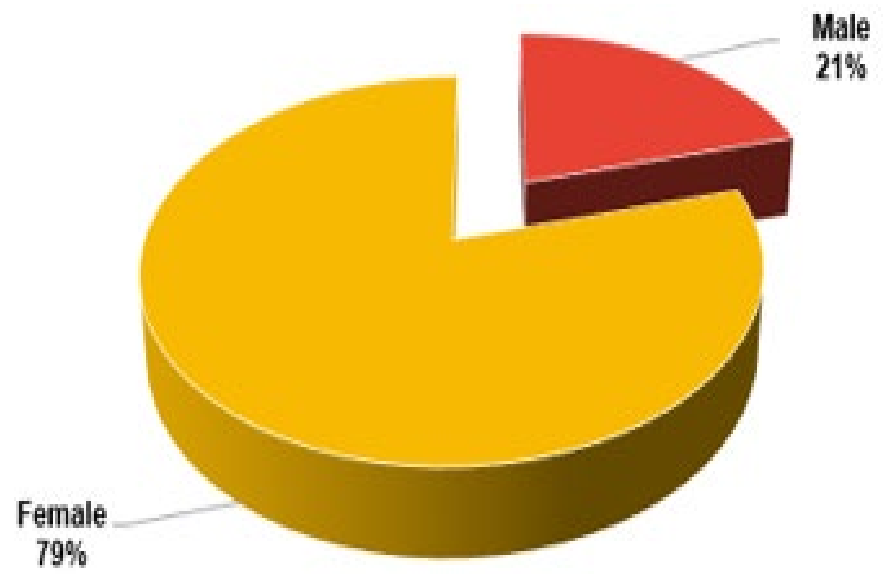

Figure 1: Respondents' Gender Pie Chart

Source: Prepared by the writer (2020)

Table 2: Respondents' Characteristics by Age

Source: Processed Data (2020)

\begin{tabular}{|c|c|c|c|c|c|}
\hline & & Frequency & Percent & Valid Percent & Cumulative Percent \\
\hline \multirow{6}{*}{ Valid } & $<20$ & 15 & 15.0 & 15.0 & 15.0 \\
\hline & $20-34$ & 67 & 67.0 & 67.0 & 82.0 \\
\hline & $35-49$ & 12 & 12.0 & 12.0 & 94.0 \\
\hline & 49 & 3 & 3.0 & 3.0 & 97.0 \\
\hline & $>49$ & 3 & 3.0 & 3.0 & 100.0 \\
\hline & Total & 100 & 100.0 & 100.0 & \\
\hline
\end{tabular}

Table 2 reveals the classification of respondents according to their age. It shows that 67 percent of the respondents belong to the age group of 20-34 years old, 12 percent respondents belong to the age group of 35-49, 3 percent is above the age of 49 . Greater than 49 years and the remaining 15 percent of the respondents belong to the age group under 20. This concludes that most of the respondents who fill the questionnaires are between 20-49 years old.

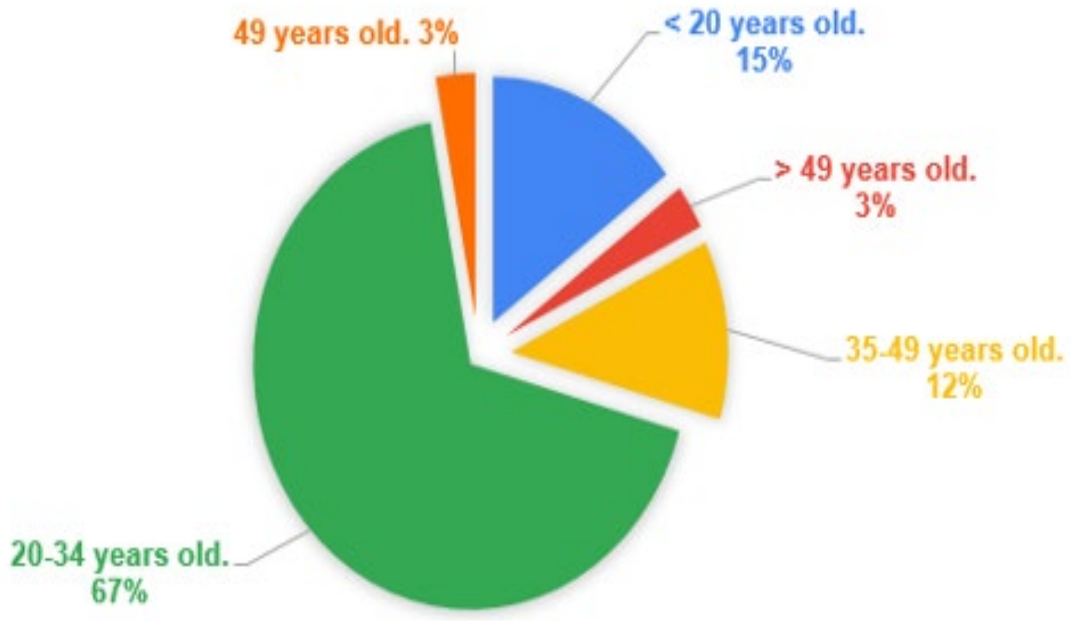

Figure 2: Respondents' Age Pie Chart

Source: Prepared by the writer (2020) 
Table 3: Respondents' Characteristics by Education Status

\begin{tabular}{|c|c|c|c|c|c|}
\hline & & Frequency & Percent & Valid Percent & Cumulative Percent \\
\hline \multirow{6}{*}{ Valid } & \multirow{6}{*}{$\begin{array}{c}\text { High School } \\
\text { Diploma } \\
\text { Bachelor's Degree } \\
\text { Master Degree } \\
\text { Doctoral Degree } \\
\text { Total } \\
\end{array}$} & 46 & 47.0 & 47.0 & 47.0 \\
\hline & & 15 & 15.0 & 15.0 & 62.0 \\
\hline & & 20 & 20.0 & 20.0 & 86.0 \\
\hline & & 15 & 15.0 & 15.0 & 101.0 \\
\hline & & 3 & 3.0 & 3.0 & 100.0 \\
\hline & & 100 & 100.0 & 100.0 & \\
\hline
\end{tabular}

Source: Processed Data (2020)

Table 3 reveals respondents' classification according to their education; 46 percent of the respondents' latest education are a high school; 15 percent has obtained a diploma as their latest education level. More than half of the respondents, 20 percent, have obtained bachelor's degrees, 15 percent have obtained a master's degree, and the remaining 3 percent hold a doctoral degree. This means that there are more bachelor's degree respondents who fill in the questionnaires.

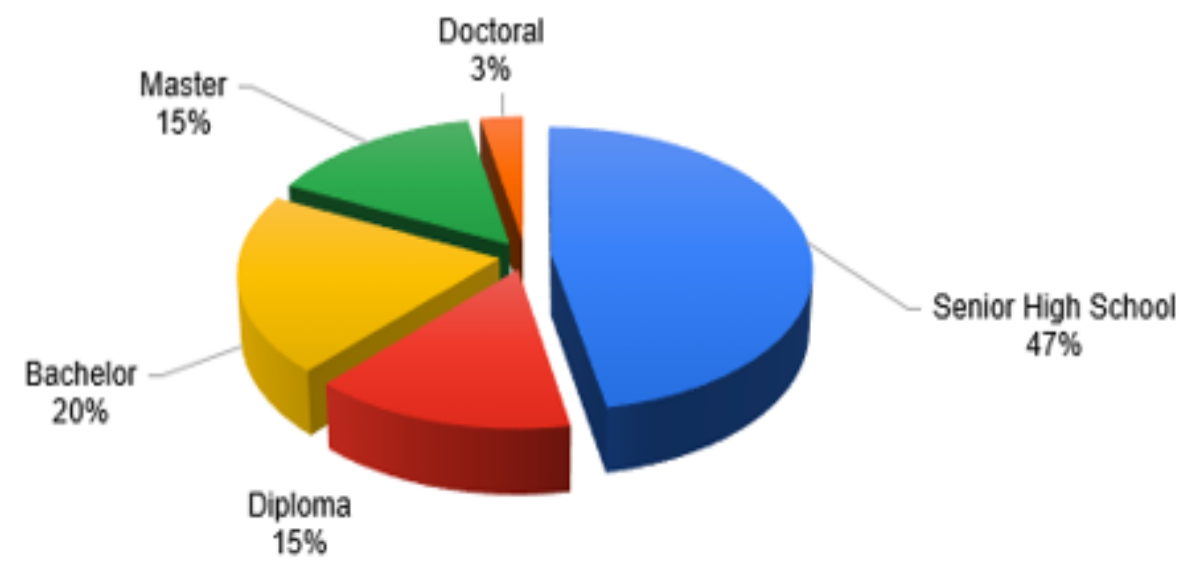

Figure 3: Respondents' Education Status Pie Chart

Source: Prepared by the writer (2020)

Table 4: Respondents' Characteristics by Occupation

\begin{tabular}{|c|c|c|c|c|c|}
\hline & & Frequency & Percent & Valid Percent & Cumulative Percent \\
\hline \multirow{5}{*}{ Valid } & \multirow{5}{*}{$\begin{array}{c}\text { Private Employees } \\
\text { Civil Servant } \\
\text { Entrepreneur } \\
\text { Tax Consultant } \\
\text { Total }\end{array}$} & 76 & 76.0 & 76.0 & 76.0 \\
\hline & & 3 & 3.0 & 3.0 & 79.0 \\
\hline & & 118 & 18.0 & 18.0 & 97.0 \\
\hline & & 3 & 3.0 & 3.0 & 100.0 \\
\hline & & 100 & 100.0 & 100.0 & \\
\hline
\end{tabular}

Source: Processed Data (2018)

Table 4 reveals respondents' classification according to their occupation; 76 percent are private employees, 3 percent are civil servants, 18 percent are entrepreneurs, and the remaining 3 percent are tax consultants. 


\section{Hantono}

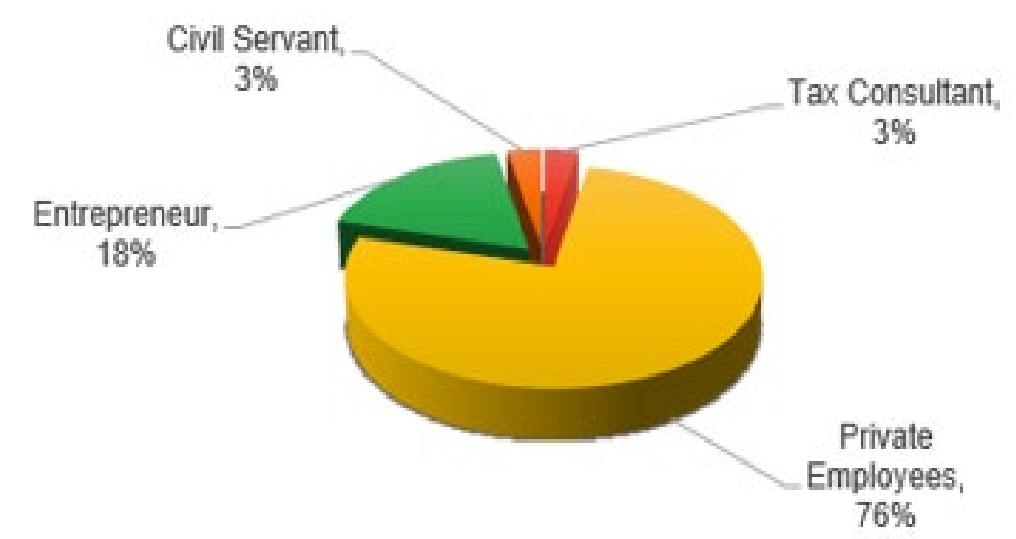

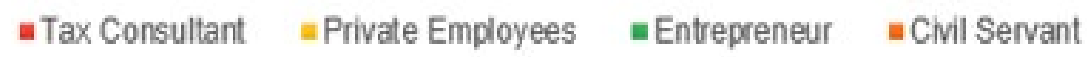

Source: Prepared by the writer (2020)

\subsection{VALIDITY TEST}

The validity test is done by comparing the value of rcount with rtable for degree of freedom (df) $=n-2(34-2)$; in this case, $\mathrm{n}$ is the number of samples. If rcount > rtable, it means that the question in the questionnaire is valid. Using the SPSS 25, all questions of each variable have rcount greater than rtable (0.338). It means that all statements are capable of measuring the object of research with valid and consistent. The value $r$ value can be seen in table 5 .

Table 5: Validity Test for Tax Knowledge

\begin{tabular}{|c|c|c|c|}
\hline Variable & Question & Pearson Correlation & Rcount > Rtable (Valid) \\
\hline \multirow{5}{*}{ Tax Knowledge (X1) } & Question 1 & 0.736 & Valid \\
\cline { 2 - 4 } & Question 2 & 0.724 & Valid \\
\cline { 2 - 4 } & Question 3 & 0.789 & Valid \\
\cline { 2 - 4 } & Question 4 & 0.753 & Valid \\
\cline { 2 - 4 } & Question 5 & 0.746 & Valid \\
\cline { 2 - 4 } & Question 6 & 0.761 & Valid \\
\cline { 2 - 4 } & Question 7 & 0.739 & Valid \\
\cline { 2 - 4 } & Question 8 & 0.714 & Valid \\
\cline { 2 - 4 } & Question 9 & 0.791 & Valid \\
\cline { 2 - 4 } & Question 10 & 0.782 & Valid \\
\hline
\end{tabular}

Source: Prepared by the writer (2020)

From the table above, the ten items or statements consist in the questionnaire for tax knowledge variable are all proved to be valid with the rcount, $0.736,0.724,0.789,0.753,0.746,0.761,0.739,0.714,0.791,0.782$, respectively, which are all greater than rtable, 0.338 .

Table 6: Validity Test for Tax Awareness

\begin{tabular}{|c|c|c|c|}
\hline Variable & Question & Pearson Correlation & Rcount > Rtable (Valid) \\
\hline \multirow{5}{*}{ Tax Awareness (X2) } & Question 1 & 0.797 & Valid \\
\cline { 2 - 4 } & Question 2 & 0.801 & Valid \\
\cline { 2 - 4 } & Question 3 & 0.768 & Valid \\
\cline { 2 - 4 } & Question 4 & 0.759 & Valid \\
\cline { 2 - 4 } & Question 5 & 0.746 & Valid \\
\cline { 2 - 4 } & Question 6 & 0.707 & Valid \\
\cline { 2 - 4 }
\end{tabular}


The Impact Tax Knowledge, Tax Awareness, Tax Morale Toward Tax Compliance Boarding House Tax

Source: Prepared by the writer (2020)

\begin{tabular}{|c|l|l|}
\hline Question 7 & 0.720 & Valid \\
\hline Question 8 & 0.717 & Valid \\
\hline Question 9 & 0.700 & Valid \\
\hline Question 10 & 0.727 & Valid \\
\hline
\end{tabular}

From the table above, the ten items or statements consist in the questionnaire for tax awareness variable are all proved to be valid with the rcount, $0.797,0.801,0.768,0.759,0.746,0.707,0.720,0.717,0.700,0.727$, respectively, which are all greater than rtable, 0.338 .

Table 7: Validity Test for Tax Morale

\begin{tabular}{|c|c|c|c|}
\hline Variable & Question & Pearson Correlation & $\mathrm{R}_{\text {count }}>\mathrm{R}_{\text {table }}$ (Valid) \\
\hline \multirow{5}{*}{ Tax Morale $\left(\mathrm{X}_{3}\right)$} & Question 1 & 0.799 & Valid \\
\cline { 2 - 4 } & Question 2 & 0.800 & Valid \\
\cline { 2 - 4 } & Question 3 & 0.800 & Valid \\
\cline { 2 - 4 } & Question 4 & 0.825 & Valid \\
\cline { 2 - 4 } & Question 5 & 0.802 & Valid \\
\cline { 2 - 4 } & Question 6 & 0.811 & Valid \\
\cline { 2 - 4 } & Question 7 & 0.789 & Valid \\
\cline { 2 - 4 } & Question 8 & 0.790 & Valid \\
\cline { 2 - 4 } & Question 9 & 0.794 & Valid \\
\cline { 2 - 4 } & Question 10 & 0.797 & Valid \\
\hline
\end{tabular}

Source: Prepared by the writer (2020)

From the table above, the ten items or statements consist in the questionnaire for tax morale variable are all proved to be valid with the rcount, $0.799,0.800,0.800,0.825,0.802,0.811,0.789,0.790,0.794,0.797$ respectively, which are all greater than rtable, 0.338 .

Table 8: Validity Test for Tax Compliance

\begin{tabular}{|c|c|c|c|}
\hline Variable & Question & Pearson Correlation & $\mathrm{R}_{\text {count }}>\mathrm{R}_{\text {table }}$ (Valid) \\
\hline \multirow{5}{*}{ Tax Compliance (Y) } & Question 1 & 0.896 & Valid \\
\cline { 2 - 4 } & Question 2 & 0.910 & Valid \\
\cline { 2 - 4 } & Question 3 & 0.885 & Valid \\
\cline { 2 - 4 } & Question 4 & 0.885 & Valid \\
\cline { 2 - 4 } & Question 5 & 0.900 & Valid \\
\cline { 2 - 4 } & Question 6 & 0.909 & Valid \\
\cline { 2 - 4 } & Question 7 & 0.893 & Valid \\
\cline { 2 - 4 } & Question 8 & 0.895 & Valid \\
\cline { 2 - 4 } & Question 9 & 0.893 & Valid \\
\cline { 2 - 4 } & Question 10 & 0.890 & Valid \\
\hline
\end{tabular}

Source: Prepared by the writer (2020)

From the table above, the ten items or statements consist in the questionnaire for tax morale variable are all proved to be valid with the rcount, $0.896,0.910,0.885,0.885,0.900,0.909,0.893,0.895,0.893,0.890$ respectively, which are all greater than rtable, 0.338 .

\subsection{RELIABILITY TEST}

Priyatno (2017) stated that a questionnaire's requirement to be regarded as reliable is when the Cronbach's Alpha is more significant than 0.60 . The results of the reliability of the variables in this research can be seen below: 
Table 9: Reliability Test Case Processing Summary

Source: Processed Data (2020)

\begin{tabular}{|cc|c|c|}
\hline & $\mathrm{N}$ & $\%$ \\
\hline \multirow{4}{*}{ Cases } & Valid & 34 & 34.0 \\
\cline { 3 - 4 } & Excluded $\mathrm{a}$ & 0 & .0 \\
\cline { 3 - 4 } & Total & 34 & 100.0 \\
\hline
\end{tabular}

Table 10: Reliability Test Reliability Statistics

Source: Processed Data (2020)

\begin{tabular}{|c|c|}
\hline Cronbach's Alpha & N of Items \\
\hline .918 & 4 \\
\hline
\end{tabular}

The result above shows that all variables have Cronbach's Alpha 0.918, which is greater than 0.60, and it can be concluded that all the variable measurements used in this research are reliable.

\subsection{NORMALITY TEST}

This research's normality test is done using Kolmogorov Smirnov and graphical analysis such as Normality P-P Plot, histogram, and scatter plot. Priyatno (2017) mentioned that decision-making criteria on this test are if the significance level $>0.05$ means $\mathrm{H} 0$ is accepted, and the data are typically distributed. The result of the Kolmogorov Smirnov test yielded from the SPSS program can be seen below:

Table 11: Normality Kolmogorov Smirnov Test

\begin{tabular}{|c|c|c|}
\hline & & Unstandardized Residual \\
\hline $\mathrm{N}$ & & 34 \\
\hline Normal Parameters,b & Mean & .0000000 \\
\hline & Std. Deviation & 3.87480755 \\
\hline & & .137 \\
\hline Most Extreme Differences & Absolute & 097 \\
\hline & Positive & -.073 \\
\hline & Negative & .137 \\
\hline Test Statistic & & $.108 \mathrm{c}$ \\
\hline Asymp. Sig. (2-tailed) & &
\end{tabular}

a) Test distribution is Normal.

b) Calculated from data.

Source: Processed Data (2020)

From the table above can be seen the significance level of the Kolmogorov Smirnov test is 0.108 . This value shows that this research's data are typically distributed because the significance level of 0.108 is more significant than 0.05 .

\subsection{MULTICOLLINEARITY TEST}

Multicollinearity can be seen through the Variance Inflation Factor (VIF) and Tolerance values. If the value of VIF is lower than 10 and tolerance greater than 0.1, then it can be concluded a regression model is good because it does not have multicollinearity by Priyatno (2017). The results are shown in the SPSS output as follows:

Table 12: Multicollinearity Test

\begin{tabular}{|c|c|c|}
\hline \multirow{2}{*}{ Model } & \multicolumn{2}{|c|}{ Collinearity Statistics } \\
\cline { 2 - 3 } & Tolerance & VIF \\
\hline 1TTax_Knowledge & .256 & 3.900 \\
\hline
\end{tabular}


The Impact Tax Knowledge, Tax Awareness, Tax Morale Toward Tax Compliance Boarding House Tax

Source: Processed Data (2020)

\begin{tabular}{|c|l|l|}
\hline Tax Awareness & .301 & 3.317 \\
Tax_Morale & .209 & 4.783 \\
\hline
\end{tabular}

a. Dependent Variable: Tax Compliance

The VIF value in the table above shows there is no strong correlation between the two independent variables. The value of VIF for both tax knowledge, tax awareness, and tax morale is lower than 10. Moreover, the value of tolerance for both independent variables show no multicollinearity in the regression model.

\subsection{HETEROSCEDASTICITY TEST}

The heteroscedasticity test is purposely examined to determine the variance inequality of residuals from one observation to another. If the variance is equal from one observation to another, it is called homoscedasticity. A proper regression model occurred when it has homoscedasticity variance, not heteroscedasticity. It is conducted by Scatterplot analysis with the following results.

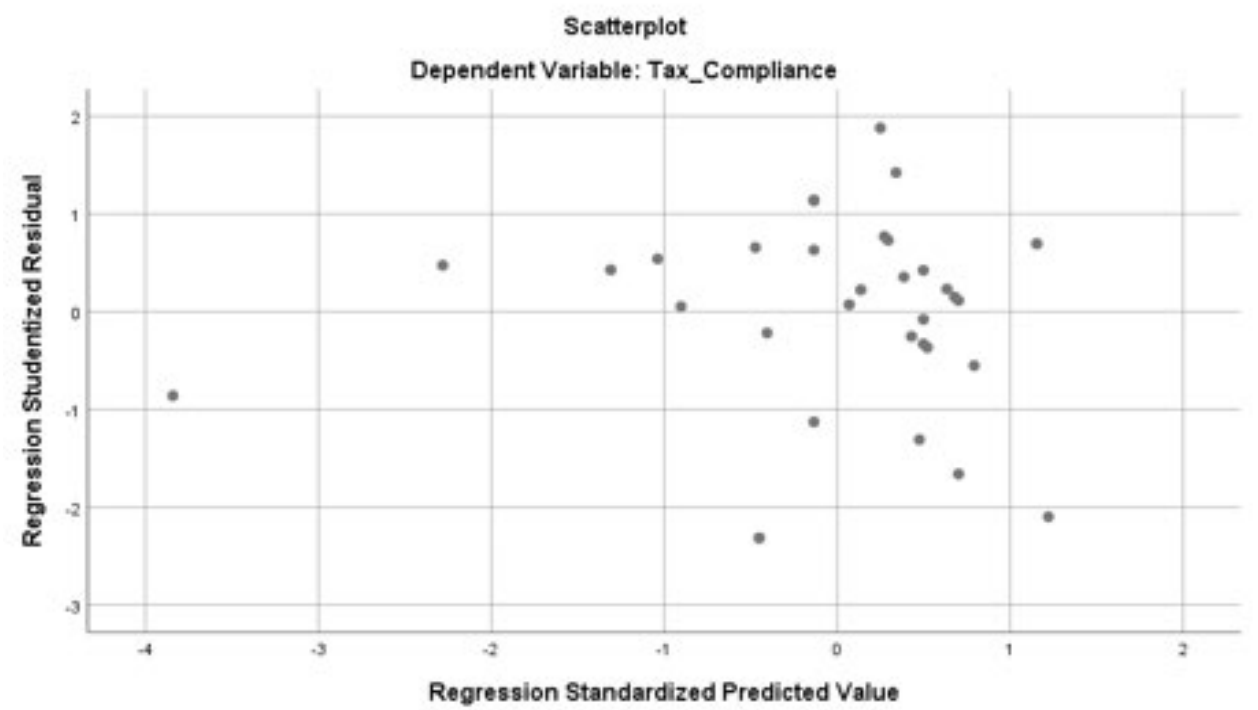

Source: Prepared by the writer (2020)

Figure 5: Scatterplot Analysis

Figure 5 shows that the dots are widely distributed, which does not create a specified pattern of distribution. It shows the residuals have a high possibility of being homoscedastic. However, the scatterplot analysis can be subjective due to visual decision making.

\section{Partial Hypothesis Testing (T-Test)}

Table 13: Partial Hypothesis Testing (T-Test)

\begin{tabular}{|c|c|c|c|c|c|}
\hline \multicolumn{6}{|c|}{ Coefficients a } \\
\hline \multirow[t]{2}{*}{ Model } & \multicolumn{3}{|c|}{ Unstandardized Coefficients|Standardized Coefficients } & \multirow[t]{2}{*}{$\mathrm{t}$} & \multirow[t]{2}{*}{ Sig. } \\
\hline & $\mathrm{B}$ & Std. Error & Beta & & \\
\hline $1 \quad$ (Constant) & -9.515 & 5.861 & & -1.623 & 115 \\
\hline Tax Knowledge & -.137 & .283 & -.094 & -.484 & .632 \\
\hline Tax Awareness & 1.223 & 267 & .826 & 4.612 & .000 \\
\hline Tax Morale & .138 & .276 & .107 & .499 & .622 \\
\hline
\end{tabular}

Source: Prepared by the writer (2020) 
The value of ttable with a two-tailed significance level of 0.05 at a degree of freedom of $30(34-3-1)$ is 2.042 . Therefore, the outcomes of partial hypothesis testing following table 6 are as follows.

1) Tax Knowledge variable has $t$ count of -.484 with a level of significance of 0.632 . It can be concluded that $t$ count $-.484<\mathrm{t}$ table 2.042 with a significance of Sig $0.632>0.05$. That means tax knowledge (X1) isn't significant toward tax compliance (Y).

2) Tax Awareness variable has t count of 4.612 with a level of significance of 0.00 . It can be concluded that $t$ count $4.612>$ t table 2.042 with a significance of Sig $0.00<0.05$. That's means tax awareness (X2) is significant toward tax compliance (Y).

3) Tax Morale variable has t count of .499 with a level of significance of .622. It can be concluded that t count $.499<\mathrm{t}$ table 2.042 with a significance of Sig $0.622>0.05$. That means tax morale (X3) isn't significant toward tax compliance (Y).

\section{Simultaneous Hypothesis Testing (F-Test)}

Table 14: Simultaneous Hypothesis Testing (F-Test)

\begin{tabular}{|c|c|c|c|c|c|c|}
\hline \multicolumn{7}{|c|}{ ANOVA $^{\mathrm{a}}$} \\
\hline \multicolumn{2}{|c|}{ Model } & Sum of Squares & Df & Mean Square & $\mathrm{F}$ & Sig. \\
\hline \multirow{2}{*}{1} & Regression & 1213.592 & 3 & 404.531 & 24.494 & $.000^{\mathrm{b}}$ \\
\cline { 2 - 7 } & Residual & 495.466 & 30 & 16.516 & & \\
\cline { 2 - 7 } & \multicolumn{7}{|c|}{ Total } & 1709.059 & 33 & & & \\
\hline \multicolumn{7}{|c|}{ b. Dependent Variable: Tax Compliance } \\
\hline
\end{tabular}

Source: Prepared by the writer (2020)

Based on table 14, the Fcount of the regression model is 24.494. The first degree of freedom (df1) $=\mathrm{k}-1=4-$ $1=3$, while the second degree of freedom (df2) $=\mathrm{n}-\mathrm{k}=34-4=30$ in which $\mathrm{n}$ represents the number of samples and k represents the amount of variables. With the df1 of 3 and df 2 of 30, the Ftable with a confidence level of 0.05 is 2.92. Therefore, the fcount $24.494>$ ftable 292 and a significance value of $0.00<0.05$ indicates that both of the independent variables are simultaneously affecting tax compliance.

\section{Coefficient of Determination (R2)}

The coefficient of determination is essentially used to measure the model's ability to explain the dependent variable's variation. The result of the determination test can be seen as follows

Table 15: Coefficient of Determination

\begin{tabular}{|c|c|c|c|c|}
\hline \multicolumn{3}{|c|}{ Model Summary $^{\mathrm{b}}$} \\
\hline Model & $\mathrm{R}$ & R Square & Adjusted R Square & Std. The error of the Estimate \\
\hline 1 & $.843^{\mathrm{a}}$ & .710 & .681 & 4.064 \\
\hline \multicolumn{4}{|c|}{ a. Predictors: (Constant), Tax Knowledge, Tax Awareness, Tax Morale } \\
\hline \multicolumn{4}{|c|}{ b. Dependent Variable: Tax Compliance } \\
\hline
\end{tabular}

Source: Prepared by the writer (2020)

Based on table 15, R Square of the regression model is 0.710 , showing that $71 \%$ of tax compliance mitigation can be explained by Tax Knowledge, Tax Awareness, and Tax Morale. Simultaneously, 29 \% of tax compliance variables can be explained by other factors or variables not examined in this research.

\section{The Impact Tax Knowledge Towards Tax Compliance}

The $t$ test on the tax knowledge variable has $t$ count $-.484<\mathrm{t}$ table 2.042 with a level of significance of 0.632 . It means H1, which hypothesizes affect tax knowledge, isn't approved. The t-test indicates tax knowledge has great impact on affecting tax compliance. This is in line with research conducted by (Winasari 2020); the more significant knowledge taxpayers, the bigger the compliance pay taxes. This proves that in meeting on tax, compliance does not need to have high knowledge about taxes. Knowledge of society's tax laws through awareness will positively affect 
the taxpayer's consciousness to pay taxes (Lestari, 2017). which states that the tax knowledge isn't towards tax compliance and It isn't also supported by research doing by Waluyo (2012). Yusuf and Ismail (2017).

\section{The Impact of Tax Awareness on Taxpayers Compliance}

The $t$ test on the tax awareness variable has $t$ count $4.612>t$ table 2.042 with a significance of Sig $0.00<0.05$. It means H2, which hypothesizes affect tax knowledge, is approved. The t-test indicates tax knowledge has less impact on affecting tax compliance. This is in line with research conducted by (Ariesta, 2017), the better awareness of taxpayers, the better compliance of taxpayers, and the higher the taxpayer's awareness, the higher the taxpayer compliance (Lydiana, 2018). Increased taxation knowledge through good tax education, formal or informal, will impact Taxpayers for Pay Taxes (Hardiningsih, 2011). This proves that the higher the taxpayer's awareness, the higher tax compliance (Lestari, 2017). The research results presented by (Al - Maghrebi et al., 2016), where their research results also revealed that the awareness of taxes affects taxpayer compliance. In their research, the obedient individual or who will obey is an individual who has awareness about taxation.

\section{The Impact Tax Morale Towards Individual Taxpayer's Compliance}

The result of t-test on tax morale variable has t count $.499<\mathrm{t}$ table 2.042 with a significance of Sig $0.622>0.05$. It means H3, which hypothesizes affect tax knowledge, isn't approved. The t-test indicates tax morale has a tremendous impact on affecting tax compliance. This is in line with Ariesta (2017) research, the better awareness of taxpayers, and the better compliance of taxpayers. The higher the awareness of the taxpayer, the higher the taxpayer compliance (Lydiana, 2018). Increased taxation knowledge through good tax education, formal or informal, will impact Taxpayers for Pay Taxes (Hardiningsih, 2011). This proves that the higher the taxpayer's awareness, the higher tax compliance (Lestari, 2017). The research results presented by (Al - Maghrebi et al, 2016), where the results of their research also revealed that the awareness of taxes affects taxpayer compliance. In their research, the obedient individual or who will obey is an individual who has awareness about taxation. Having the awareness that paying taxes is mandatory and can finance the state. the higher the level of tax knowledge of taxpayers, the higher the tax compliance rate taxpayer (Puspita, 2016).

\section{ABOUT THE AUTHORS}

Hantono earned his Bachelor of Economics, Departement of Accounting, University of Methodist Indonesia, Bachelor of Mathematics, STKIP Pelita Bangsa, Postgraduate Master Faculty of Economics, Medan State University, Accounting Professional Education, University of North Sumatera, Certified Accurate Professional (CAP), Junior Technician Competency Certification. Presenter in University of Widya Mandala, Surabaya, Presenter in Faculty of Economics and Business, University of Indonesia 2 and 3 August 2017, International Conference and Doctoral Colloquium in Finance 2017, Presenter on the 4 th Sebelas Maret International Conference on Business, Economics and Social Sciences, 10 th August 2017, Solo. Presenter at The National Tax Symposium, University Trunojoyo, Presenter at The Scientific Accounting Symposium 2018, Postgraduate School, University of Prima Indonesia (UNPRI), Presenter on Temu Masyarakat Akuntansi Multiparadigma Indonesia ke - 6 TEMAN 6 (20 - 21 July 2018) in University of Airlangga, Surabaya, Advisor and Assistant for Indonesian Taxation Contest Activities at the Bali State Polytechnic in 2017 as well as being the jury board for the Indonesian Taxation Competition at the Bali State Polytechnic, In 2015, Won 2 nd Runner Up in the Scientific Writing Competition at the Research Agency and Medan City Development (Medan City Balitbang). In 2016, Won 3rd Place in Scientific Writing Competition at the Medan City Research and Development Agency (Balitbang Kota Medan). He authored some publications. His current research interests: finance, audit, tax.

\section{SOURCES OF FUNDING}

This research received no specific grant from any funding agency in the public, commercial, or not-for-profit sectors. 
Hantono

\section{CONFLICT OF INTEREST}

The author have declared that no competing interests exist.

\section{ACKNOWLEDGMENT}

None.

\section{REFERENCES}

[1] Alm, J., \& Torgler, B. (2006). Culture Differences and Tax Morale in the United States and in Europe. Journal of Economic Psychology, 27(2), 224-246.

[2] Agustini, IGAPratama. 2008. Effects of Subjective Norms, Moral Obligations and Quality of Service Against Compliance with Corporate Taxpayer Reporting on West Denpasar Primary Tax Office (Case Study of the Company Construction in Denpasar City). Thesis. University's Faculty of Economics Udayana.

[3] Al-Maghrebi, Mohammed S., Ahmad, Riayati, \& Palil, Mohd R. (2016). Budget Transparency and Tax Awareness Towards Tax Compliance: A Conceptual Approach. South East Asia Journal of Contemporary Business, Economics and Law, Vol.10 No.1:95-101.

[4] Artha, Ketut Gede Widi and Putu Ery Setiawan. (2016). Effect of Moral Liability, Quality of Service, Taxation Sanctions in Tax Compliance Compliance in The North Badung KPP. E-Journal of Udayana University Accounting. Vol.17.2: 913 - 937.

[5] Ariesta, Ristra Putri and Lyna Latifah (2017). Influence of Tax Awareness Awareness, Taxation Sanctions, Modern Taxation Administration System, Knowledge Corruption, And Tax Amnesty Against Tax Obligation in KPP Pratama Semarang. Accounting Beware Vol. 1 No. 2.

[6] Asfa, Rizqiana Esti and Wahyu Meiranto. (2017). Effect of Taxation Sanctions, Fiscus Services, Knowledge and Understanding Taxation, Awareness Taxation on Tax Compliance Compliance. Diponegoro Journal of Accounting. Vol.6. No.3. Page $1-13$.

[7] Chandrarin, G. (2017). Metode Riset Akuntansi Pendekatan Kuantitatif. Jakarta: Salemba Empat.

[8] Cuccia, A. (2013). The Economics of Tax Compliance: What Do We Know and Where Do We Go? Journal of Accounting Literature, 13, 81-116.

[9] Dewi, Anak Agung Sri Intan Komala and Putu Ery Setiawan (2016). Influence of Awareness, Quality of Service, Liability Moral, and Perception of Taxation Sanctions on Compliance Mandatory Tax Record. E-Journal of Udayana University Accounting. Vol.17.1. pp. $84-111$.

[10] Damajanti, Anita., Abdul Karim. (2017). Effect of Tax Knowledge on Individual Taxpayers Compliance. Economics \& Business Solutions Journal Volume 1, Number 1, 2017, 1-19.

[11] Frey, B. S. and Torgler, B. (2007). Tax Morale and Conditional Cooperation. Journal of Comparative Economics, 35(1), 136-159.

[12] Hantono. 2020. Metodologi Penelitian Skripsi dengan Aplikasi SPSS. Yogyakarta: Deepublish.

[13] Hasseldine, J., Holland, K. and Rijt, P.V. (2009) The Management of Tax Knowledge. The Association of Chartered Certified Accountants, ACCA, London. www.accaglobal.com.

[14] Ho, Daniel. 2009. A Study of Hongkong Tax Compliance Ethics. International Business Research, 2 (4).

[15] Hardiningsih, Pancawati. (2011). The Factors That Influence the Willingness to Pay the Tax. Dynamics of Finance and Banking. Vol. 3. No..1. Pages: $126-142$.

[16] Halla M. (2012). Tax Morale and Compliance Behavior: First Evidence on a Causal Link, The B.E. Journal of Economic Analysis \& Policy, 12(1), 1935-1682.

[17] Hartini, Oki Sri and Dani Sopian. (2018). Effect of Taxation Knowledge and Awareness Awareness Tax on obligation of Personal Tax Obligation (Case Study at Karees Primary Tax Service Office). Journal Management and Accounting. Vol.X. No.2.

[18] Harefa, Meilinda Stefani and Gusniar Enjel Gea. (2019). Analysis of Factors Affecting Mandatory Obligations in Tax Private Persons Report Annual Notification Letters. Journal of Economic and Business. Vol. 01. No.01. Page 30 - 39. 
The Impact Tax Knowledge, Tax Awareness, Tax Morale Toward Tax Compliance Boarding House Tax

[19] Jotopurnomo, Cindy and Yenni Mangonting. (2013). Effects of Taxpayer Awareness, Quality Fiscus Services, Tax Sanctions, Environmental Taxpayers Reside Personal Taxpayer Compliance in Surabaya. Tax \& Accounting Review, Vol. 1 Number 1. Pp. 50-54.

[20] James, S. and Alley, C. (2004) Tax Compliance, Self-Assessment and Tax Administration. Journal of Financial and Management in Public Services, 2, 27-42.

[21] Jayawardane, D. (2016). Taxpayer Attitude and Tax Compliance Decision in Sri Lanka,International Journal of Arts and Commerce, Vol. 5 No. 2, p. 124.

[22] Layata,Sherly and Putu Ery Setiawan.(2014). Effect of Moral Liability, Quality of Service, Tax Audit and taxation sanctions on Corporate Tax Payer Compliace. E-Journal of Accounting, Udayana University. Pp 540 556.

[23] Lydiana (2017). Effect of Tax Awareness Awareness, Knowledge Taxes, and Tax Sanctions on Compliance Individual Tax Obligations in KPP Pratama Surabaya Gubeng. Calyptra: University of Surabaya Student Scientific Journal Vol.7 No.1.

[24] Lestari, Tutik., Monot Wicaksono. (2017). Effect of Awareness, Knowledge, and Attitude of Taxpayers Tax Compliance for Taxpayers in Tax Service Office Boyolali. International Journal of Economics,Businessand Accounting Research (IJEBAR). Vol.1. Issue - 1.

[25] Marziana Hj. Mohamad, Norkhazimah Ahmad, Mohmad Sakarnor Deris (2010): Perceptions of Taxpayers with Level of Compliance: A Comparison in the East Coast Region, Malaysia: Journal of Global Business and Economics, vol.1, issue 1, pages 241-257.

[26] Marti, O.L. (2010), Taxpayers'attitudes and Tax Compliance Behavior in Kenya, African Journal of Business and Management, Vol. 1 No. 1, pp. 112-122.

[27] Muliari, Ni Ketut and Putu Ery Setiawan. (2011). The Effect of Perception About Tax Sanctions and Taxpayer Awareness on Compliance Reporting an Individual Taxpayer at the Tax Service Office Pratama East Denpasar. Journal of Accounting at Udayana University. Vol. 6.No. 1.

[28] Resmi, Siti. (2009). Taxation Theory and Cases, Fifth Edition, Salemba Four, Jakarta

[29] Rajif, Mohamad. (2012). Influence of Understanding, Quality of Service, and Decisive Sanctions Taxation of Tax Compliance SME Entrepreneurs in Cirebon Area. Faculty of Economics Department of Accounting Gunadarma University, Journal Gunadarma.

[30] Puspita, Ayu Fury.,Bambang Subroto, Zaki Baridwan. (2016). The Analysis of Individual Behaviour of Corporate Taxpayers' Obedience: Tax Compliance Model (Study of Hotels in Malang and Batu). Review of Integrative Business and Economics. Vol.5. No.3.

[31] Priyatno, D. (2017). Panduan Praktis Olah Data Menggunakan SPSS. Yogyakarta: Penerbit Andi.

[32] Rosito, Nunung Cahyo. 2010. Analysis of the Effect of Income Level, Organizational Culture and Moral Obligations in Compliance of Individual Taxpayers in Compliance Income Tax Obligations. Thesis of the Faculty of Economics, Muhammadiyah University.

[33] Sugiyono. (2017). Metode Penelitian Kuantitatif, Kualitatif, dan R\&D. Bandung: CV Alfabeta.

[34] Subarkah, Johny and Maya Widyana Dewi. (2017). Influence of Understanding, Awareness, Quality of Service, and Sanctions of Sanctions on Mandatory Compliance Personal taxes in KPAT Pratama Sukoharjo. Journal of Accounting and Taxes, Vol. 17, No. 02.

[35] Setiawan, Sandy and Harnovinsah. (2019). Analysis of Factors Affecting Individual Taxpayer's Compliance. International Journal of Business and Management Invention (IJBMI). Vo.8. Issue.3. P.P. 26 - 33.

[36] Semaraputri, I.G.A.A.Pradnya Anintya and I Gusti Ayu Intan Saputra Rini. (2019). Influence of Perceptions About Tax Sanctions, Taxpayer Awareness, Quality Services, Moral Obligations of Corporate Taxpayer Compliance in KPP Gianyar Pratama. Discourse on Economics (Journal of Economics, Business and Accounting). Vol.18. No.1. pp 52 - 55.

[37] Torgler, B. (2007). "Tax Compliance and Tax Morale: A Theoretical and Empirical Analysis". Cheltenham, U.K.: Edward Elgar Publishing, Massachusetts.

[38] Taxpayer Rights and Obligation Handbook Ministry of Finance. 2011 Accessed via the website: http: //pajak.go.id/content/book-hak-dan- obligation-tax-2011-obligation.

[39] Yusnidar, J. (2015). The Influence of Factors Affecting Obligatory Compliance Taxes in Making Tax Payments Earth and Rural Buildings and Cities (Study on U.N. Taxpayers- P2 District Jombang Regency Jombang. Department of Business Administration Brawijaya University, Taxation Journal (TRACT) Vol. 1 No. 1 January 2015. Accessed April 22, 2015. Pg. 1-10. 
[40] Yusuf, Muhammad \& Ismail, Tubagus. (2017). The Effect of Tax Knowledge, Zakat Knowledge and Attitudes Toward Muslim Taxpayer's Compliance.Transparancy, Vol. 9, Number 02, 2017 September, Journal of Administration Science. ISSN 2085-1162, 223-243.

[41] Yadnyana, I Ketut. 2010. Influence of Moral and Attitudes of Taxpayers on Obligatory Compliance Cooperative Tax in the City of Denpasar. Bulletin of Economic Studies, 15 (1): h: 75-81, Denpasar: Faculty of Economics, Udayana University.

[42] Widayati and Nurlis. (2010). Factors Which Affect the Will to Pay Tax Payers Private People Who Run Profession Free ", Simposium National Accounting XIII. Purwokerto.

[43] Widiyanto, Joko. (2010). SPSS for Windows Untuk Analisis Data Statistik dan Penelitian. Surakarta: BP-FKIP UMS.

[44] Waluyo. (2012). The Effects of Tax Services, Perception of Tax Systems, Knowledge of Taxes, and Tax Awareness on Individual Taxpayer Compliance. Journal of Binaniaga Vol.08 Number.1, 2012.89-97.

[45] Winasari, Anggi. (2020). Effect of Knowledge, Awareness, Sanctions, and E-Samsat System of Tax Obligation Motor Vehicles in Subang District. (Case Study at Subang Samsat Office). Prisma (Accounting Student Research Platform). Volume 01 Number 01 Pages. 